\title{
Redefining Water Treatment: Identification of WWTPs as an Earth System Problem and Circular Economic Eco-Bog System to Challenge It
}

\author{
Adem Bilgin and Günay Erpul
}

\section{ABSTRACT}

Wastewater Treatment Plants (WWTPs) on the planet, daily processing billions of tons of wastewater and producing masses of sludge accordingly, act like artificial biogeochemical cycles themselves by producing material flow and creating microbial life cycles that normally do not exist in nature, a case with unknown cumulative long-term effects on the planet and human organisms. This study identifies WWTPs as a general Earth system problem with sub-problems to be challenged by new engineering techniques with an integrated natural science perspective. In order to challenge these problems, first the overall ecological role of WWTPs is clarified. Second a literature review (a) on the contents of the end products of wastewater engineering (b) on the effects of utilization of sewage sludge as fertilizer (c) on the utilization of sewage sludge as cement and construction material is provided. Current legal and practical situation in Turkey and EU is very briefly compared. Then, the design of the circular economic eco-bog system, which is a conceptual model of a new technology both to challenge these problems as much as possible and to act as an integrated industrial production system, is introduced. The new system is based on an innovative algaculture and ecomimicry of the evolution of wetland ecosystems from lake to terrestrial ecosystems. Algaculture and artificial bog components of the system use desulphurised fuel gases from both biogas component of the system and also concrete production component of the system. Desulphurization is to avoid $\mathrm{H}_{2} \mathrm{~S}$ production in eco-bog unlike the natural bog ecosystems, and produce sulphurous fertilizers, and produce bog ecosystem services. Since, the fuel gas utilization from the biogas produced by archaebacteria is already net carbon zero, all system makes negative emission, namely sequestration. The $\mathrm{CO} 2$ to be released is fixed as biocarbon in algae in agriculture component, and then as organic and inorganic carbon after the sedimentation during accelerated evolution of eco-bog by creating hypoxia, acidification, and eutrophication conditions in artificial lake ecosystem. This sedimentation is mixed with sewage sludge ash for production of cement to have a higher quality concrete. Microbial biofertilizer and organic fertilizers are also produced from the algaculture component of the system, and industrial lichen from bog ecosystem. The system is inspired from lake death mechanisms of the nature, rather than lake health mechanisms in order to capture carbon and nitrogen in lithosphere and biosphere rather than releasing them to atmosphere as fuel gases, imitating natural bogs which are important carbon reservoirs. Finally, a new theorization of the issue is postulated as a way forward to reach SDGs, circular economy and bioeconomy targets of EU Green Deal as well as targets of RIO Conventions and Paris Agreement, not based on water quality arguments but based on mass and energy arguments, as well as arguments for ecologic health and preventive medical treatment for public health, and arguments for integrated industrial production in a holistic manner.

Keywords: Accelerated Ecosystem Evolution, Carbon Sequestration, Earth system, Ecomimicry, Wastewater Treatment Engineering
Published Online: June 05, 2021

ISSN: $2684-446 \mathrm{X}$

DOI : 10.24018/ejgeo.2021.2.3.141

Adem Bilgin

Ministry of Agriculture and Forestry, DGNCNP, Department of Nature Conservation, Research and Development Working Group, 06560, Ankara, Turkey.

(e-mail: bilgin.adem @ tarimorman.gov.tr) Günay Erpul

Department of Soil Science and Plant Nutrition, Faculty of Agriculture, University of Ankara, 06110, Ankara, Turkey.

(e-mail: Gunay.Erpul@ankara.edu.tr)

*Corresponding Author 


\section{INTRODUCTION}

\section{A. Identification of the Problem}

To achieve circular economy in wastewater treatment, a new theoretical approach in harmony with nature and with maximum recycling and carbon capture is needed. WWTPs act like artificial biogeochemical cycles themselves and additional cyclic components may also be integrated [1]-[3]. This study identifies WWTPs as a component and a general problem of Earth system (Table I). Because WWTPs; wherever they are located on the Planet, both have niche in Earth system with their biotic and abiotic environmental interactions and produce sewage sludge ecosystems with population dynamics of many microbial species [IV] and thus when recycled as fertilizers they produce unnatural life cycles which further create biotic and abiotic interactions with their environment.

TABLE I: WWTPS PROBLEM AND SUB-PROBLEMS TO BE CHALLENGED BY ENGINEERING AND TECHNOLOGY

\begin{tabular}{|c|c|c|c|}
\hline \multicolumn{4}{|c|}{ EARTH SYSTEM PROBLEM } \\
\hline $\begin{array}{c}\text { Major } \\
\text { Ecological } \\
\text { Problem } \\
\end{array}$ & $\begin{array}{l}\text { Problem for } \\
\text { Biology of } \\
\text { Organisms }\end{array}$ & $\begin{array}{c}\text { Erroneous } \\
\text { Philosophy of } \\
\text { Engineering }\end{array}$ & Legal Problem \\
\hline $\begin{array}{l}\text { - Atmosphere } \\
\text { interactions of } \\
\text { WWTPs } \\
\text { - Hydrosphere } \\
\text { interactions of } \\
\text { WWTPs } \\
\text { - Lithosphere } \\
\text { interactions of } \\
\text { WWTPs } \\
\text { - Biosphere } \\
\text { interactions of } \\
\text { WWTPs } \\
\text { - Anthroposph } \\
\text { ere interactions } \\
\text { of WWTPs }\end{array}$ & $\begin{array}{l}\text { - Heavy metal } \\
\text { accumulation in } \\
\text { species due } \\
\text { WWTPs } \\
\text { - Biomagnifica } \\
\text { tion and various } \\
\text { other effects of } \\
\text { contaminants } \\
\text { (including } \\
\text { contaminants of } \\
\text { emerging } \\
\text { concern) } \\
\text { species } \\
\text { - Creation of } \\
\text { unnatural } \\
\text { pathogenic life } \\
\text { cycles } \\
\text { WWTPs by } \\
\text { - Unnatural } \\
\text { spread of genes } \\
\text { (such an as } \\
\text { antibiotic } \\
\text { resistance genes } \\
\text { in bacteria) }\end{array}$ & $\begin{array}{l}\text { - Ill-defined } \\
\text { purpose of } \\
\text { wastewater } \\
\text { treatment } \\
\text { engineering } \\
\text { - Neglecting the } \\
\text { role of the physical } \\
\text { law of } \\
\text { conservation of } \\
\text { mass } \\
\text { evolutionary } \\
\text { ecosystem ecology } \\
\text { - Neglecting the } \\
\text { fact that sewage } \\
\text { sludge is an } \\
\text { artificial } \\
\text { ecosystem end } \\
\text { product of } \\
\text { engineering, ready } \\
\text { to enter multiple } \\
\text { ecological cycles } \\
\text { in open biosphere }\end{array}$ & $\begin{array}{l}\text { - Lack of } \\
\text { biosolid relevant } \\
\text { legislations in } \\
\text { some countries } \\
\text { - Lack of } \\
\text { appropriate } \\
\text { human health } \\
\text { and } \\
\text { environmental } \\
\text { health concerns } \\
\text { in existing } \\
\text { biosolid relevant } \\
\text { legislations }\end{array}$ \\
\hline
\end{tabular}

\section{B. Elaboration of the Theoretical Details of the Problem}

Ref. [5] defines wastewater treatment for EUROSTAT, broadly differentiating primary, secondary and tertiary treatment types, as a process to systematize wastewater suitability to satisfy feasible environmental standards or other quality norms for recycling or reuse. Encyclopedia Britannica definition is "the removal of impurities from wastewater, or sewage, before it reaches aquifers or natural bodies of water such as rivers, lakes, estuaries, and oceans." [VI] Although both definitions are not wrong, and successfully describe the state of the art, they are clearly water based arguments, rather than holistic Earth system based arguments. With a top view Earth system perspective, the WWPTs embedded in and distributed to different parts of the Earth surface have a role in material flows within the planetary system; with a philosophy of engineering oriented to an ideal value of production of the cleanest water possible to a part of the hydrosphere (i.e., wetland and marine ecosystems to be discharged, or groundwater when used in agricultural irrigation) by pulling some mass and energy from wastewater of urban ecosystems, which is another part of the hydrosphere. Thus, the more this water quality ideal value is realized, the more the engineering is successful. However, physically this ideal value is also equivalent to producing the ideally dirtiest sludge possible.

The removed mass and energy from hydrosphere enter into atmosphere, lithosphere and biosphere, and this total mass replaced among Earth layers includes a mass of contaminants and a biomass of a microbial biodiversity which also have a capacity to have further mass and energy interactions with the environment they are relocated to. Basically, wastewater treatment engineering has been focusing on one single straight purpose: to produce maximum quality of treated water ready to be discharged or reclaimed, with a remnant of sludge to be recycled on Earth layers other than hydrosphere. Nevertheless, contents of this mass such as phosphorus circulates in open Earth system and some paths of biogeochemical cycles lead back to the aquatic ecosystems. Thus, separation of some mass and energy from hydrosphere by WWTPs is temporal, lasting a period very short at evolutionary ecosystem ecology scale. The process also produces fuel gases to atmosphere. Furthermore, utilization of sewage sludge as fertilizer has an ecological role not only by creating new material flow but also by creating new microbial life cycles in natural, semi-natural and urban landscapes.

These processes are not sustainable and not form a successful environmental struggle at Earth science level, a multidisciplinary science which is taking into account of both the biogeochemical cycles and the physical law of conservation of mass.

\section{Literature on the Contents of Sewage, Sewage Sludge and Fertilizer Made from Sewage Sludge}

There is a huge literature from various sciences and disciplines indicating the risks associated with the endproducts of wastewater engineering.

\section{1) Microbiology and Medical Microbiology}

Sewage has a microbial biodiversity including organisms of protozoa, parasitic worms, bacteria, and viruses [7], [8] and sewage sludge also contains methanogenic archaebacteria if biogas production is part of wastewater treatment process. Microbial organisms are observed in both treated and untreated sewage sludge [9] and WWTPs are not capable of entirely eliminating Taenia spp. eggs. [10] Also, [4] have measured abundant life in activated sewage sludge while it is being processed in 13 Danish WWTPs with nutrient removal in consecutive years. In their study for UNEP [8] lists (a) Salmonella, Shigella, Campylobacter, Vibrio cholera among the bacteria, (b) Hepatitis A, Rotavirus, Enterovirus among the viruses, (c) Entamoeba histolytica, Giardia lamblia, Cryptosporidium parvum among the protozoa, (d) Helminths, Ascaris, Ancylostoma, Trichuris among the parasitic worms and their eggs. Ref. [11] identified large numbers of Escherichia coli (male strain) in human wastewater, mostly originating from human feces. Viruses can adsorp on surfaces in sewage depending on the $\mathrm{pH}$, because when they are in water, they are charged colloidal particles. [12] The infamous coronavirus type Sars-Covid2 that has been causing a global pandemic is found to be surviving to have a life cycle through 
sewage and even treated water [12], [13]. Ref. [14] reported that Israel experienced an outbreak of wild poliovirus type 1, which was traced through environmental surveillance of the sewage system in 2013-2014. World Health Organization, listing 28 parasitic species on human stool, indicates a need for further study within the disciplines of sanitary parasitology, microbiology, and sanitary engineering. [15]

\section{2) Chemistry, Biochemistry and Soil Science (Heavy Metals)}

Heavy metals are shown to be accumulating in agricultural plant organisms when sewage sludge is used as fertilizers, significantly in sunflower roots but not in leaves [16] and accumulate in Beta vulgaris. [17] A 1987 study in UK, when UK was regulating the issue by the EU directive 86/278/EEC (Sewage Sludge Directive), has shown notable rises in $\mathrm{Cd}$, $\mathrm{Ni}, \mathrm{Cu}$ and $\mathrm{Zn}$ concentrations in the edible portions of wheat, potato, lettuce, red beet, cabbage, and ryegrass, whereas lead was unavailable for plant uptake. [18] The latter is confirmed by [19] as well. "Plants differ in their abilities to absorb sludge-derived metals from the soil." [20] Determining the heavy metal limitations for sludge utilization as fertilizer should also consider the long-term heavy metal accumulation risks [19]. If metals applied onto an ecosystem are not taken by plants they can remain on water, or move to aquifer; in which soil structure, climate and rainfall also have an important role. Ref. [21] using analysis of variance (PROC ANOVA) measured that soil quality is not affected by repeated sewage sludge (Class B of US-EPA) application in South Florida where there is a large cattle industry, and subtropical climate. Ref. [22] maps only south tip Florida together with Hawaii as tropical climate zones in US by Köppen Climate Classification map. Ref. [21] is also indicating that no fertilizer application was done in 2002, implying the role of 2002 Florida rainfall in removal of molecules from soil, which is Pomona fine sandy soil taken from soil depths of (a) 0- to 20 (b) 20- to 40 (c) 40- to 60 (d) 60 - to 100 centimeters. Pomona fine sandy soil is sandy and siliceous and has hyperthermic ultic alaquods. [23] Based on heavy metal concentration measurements, [24] claims that composting of sewage sludge is a process to transform a less stabilized waste into a material, and any longer that is not classified as a waste. Ref. [25] proposes indirect application of municipality sewage sludge could considerably reduce heavy metal pollution as in manufacturing net bags. All types of municipal solid waste originated compost are also shown to contain concentrations of heavy metals in much greater amounts than natural background values of soil based on an analysis of international data. [19] For Earth system, heavy metals coming from municipality facilities of human settlements, are mostly industrially originated and do not belong to the natural ecosystems and semi-natural agricultural ecosystems they are spread onto.

\section{3) Chemistry and Biochemistry (CEFs)}

Indeed, chemical pollution problem by sewage sludge is far beyond the heavy metal problem. Ref [26] indicated contaminants of emerging concern (CEFs) that comprise "pharmaceuticals and personal care products, microplastics, engineered nanomaterials, per- and polyfluoroalkyl substances, flame retardants, plasticizers, metals, antibiotic resistance bacteria, and resistance genes may have undesirable effects on the environment and, ultimately, on the human health" through as crops grown under sludgeamended soils are consumed. Bacteria, when obtain antibiotic resistance genes pose a threat to the health of humans and other animals, as well as plants and fungi when they are given a new life cycle by sludge and reclaimed water, which is also a case with an economic meaning of additional costs to the society with regards to medicine, veterinary sciences, and agriculture. Although it is difficult and expensive to selectively remove all of the contaminants of emerging concern, there are methods to remove; pharmaceutical micropollutants [27], antibiotic resistance genes [28], [29], antibiotics [30] and microplastics [31].

\section{4) Nanotechnology}

Nanotechnology, having a capacity to produce totally unnatural molecules and processes; both causes pollution and also seems to be promising a role in wastewater treatment. Ref. [32] addresses the risk for humans and nature arising from fabrication of molecular assemblies and microbial array chips, which are widely used in agricultural and environmental sectors and various industries. Ref. [33], criticizing the conventional wastewater treatment technologies to be focusing on primary treatment and producing toxic doses of phosphorus ions and other ions, addresses the potential of utilization of nanomaterials and nanosorbents in advancing the existing technology.

\section{5) Chemistry, Biochemistry and Agriculture (PFAs)}

Per- and polyfluoroalkyl substances, (PFAs) are of emerging concern for aquatic ecosystems, thus agriculture and food health, and their amount to be treated also depends on the industrial facilities which are discharging into sewage. In Australia, which is a developed country, [34] calculated the mean $\sum$ PFAS to be $110 \mathrm{ng} / \mathrm{L}$ from samples taken from 19 WWTPs, investigating 21 types of PFAs in solid and aqueous samples. In Assamra WWTP discharging into Zarqa River in Jordan, which is a developing country, [35] have calculated the influent $\sum$ PFAS to be $10-15 \mathrm{ng} / \mathrm{L}$ and effluent $\sum$ PFAS to be 14-24 ng/L, concluding that treatment in the facility was poor. Ref [35] also compared an unaffected upstream tributary (Sukhna station) in Zarqa River with $\sum$ PFAS value 4.5-5.4 ng/L, with farther downstream Zarka River with $\sum$ PFAS value $16-27 \mathrm{ng} / \mathrm{L}$ which is a case clearly indicating an increased pollution, albeit the concentration is not that much as developed and industrialized countries and do not cause accumulation in alfalfa and mint plants according to experimental results.

\section{6) Chemistry (Flame Retardants and Plasticizers)}

Among the polybrominated diphenyl ether (PBDEs) type flame retardants, [36] detected hexabromobenzene (HBB), 1,2-bis(2,4,6-tribromophenoxy)ethane (BTBPE), 2ethylhexyl 2,3,4,5-tetrabromobenzoate (TBB), $\operatorname{di}(2-$ ethylhexyl)-2,3,4,5-tetrabromophthalate (TBPH), the chlorinated flame retardant Dechlorane Plus (syn- and antiisomers), and the antimicrobial agent 5-chloro-2-(2,4dichlorophenoxy)phenol (triclosan) in all their sample biosolids with a measured value range of $\Sigma$ PBDE between from 1750 to $6358 \mathrm{ng} / \mathrm{g}$ (dry weight) in their study on biosolids taken from two WWTPs in North Carolina and two WWTPs in California. Organophosphate flame retardants (OPFRs) are used as flame retardants and plasiticisers. Ref. 
[37] measured $4.14 \mathrm{ng} / \mathrm{g}$ (dry weight) and $7290 \mathrm{ng} / \mathrm{g}$ (dry weight) concentrations for tripropyl phosphate (TPP) and tris(2-butoxyethyl)phosphate (TBOEP) on sewage sludge from a WWTP in New York, indicating incomplete removal. TRIS molecules are infamous for being used in baby products, textile, and some consumer products. Chlorination in WWTPs produce both brominated flame retardants (BFRs) and phosphorus flame retardants (PFRs), including TRIS molecules (triphenyl phosphate (TPhP), tricresylphosphate (TCP), tris(2-chloroethyl)phosphate (TCEP), tris(chloropropyl)phosphate (TCPP), tris(1,3-dichloro-2propyl)phosphate (TDCPP), and tetrekis(2chlorethyl)dichloroisopentyldiphosphate (V6)) and these cancerogenic chlorinated BFRs and the TRIS are not readily removed by WWTPs. [38]

7) Life Cycles, Biogeochemical Cycles, Biogeography, Ecosystem Energetics and Veterinary Biochemistry

Within the hydrosphere, both lentic and lotic ecosystems are vulnerable to hypoxia due fertilizers through aquifer contamination. Ref. [39] indicates that sewage sludge fertilization related aquifer contamination by nitrogen can also lead to anoxia of rivers and fish death. Hypoxia also diminishes ecosystem functions of benthic organisms in estuaries. [40] Sedimentation due termination of life in wetlands, has a biogeographical risk for change of the wetland into terrestrial landscape. With regards to biology of individual organisms, when contaminants enter into ecosystem via any ecological pathway, the flow of their mass via food chain energetics causes the highest accumulation in top-predators with a process known as biomagnification. In a comprehensive review of 37 previous studies between 20022012 on the accumulation of flame retardant and plasticizer origin in European raptors, [41] report accumulation of perfluoroalkyl substances (PFASs), novel flame retardants (NFRs), and to a lesser extent accumulation of UV-filters, neonicotinoids, chlorinated paraffins, parabens and bisphenols in mostly matrices, eggs, feathers and plasma of the white-tailed eagle (Haliaeetus albicilla), peregrine falcon (Falco peregrinus) and northern goshawk (Accipiter gentilis). Neonicotinoid pesticides not only kill bees, but also accumulate in top-predators.

\section{Brief Comparison on Legal and Practical Situation in Turkey and EU}

Turkey limits heavy metals and only Escherichia coli as a pathogen, with the 2010 Bylaw on Landuse of Domestic and Urban Wastewater Sludge. Before 2010, the issue was not regulated. For the termination of Escherichia coli, a heating process up to 775 Celsius degrees in ovens for at least 3 hours is requested by the bylaw which would terminate all life; however, this rule is practically not obeyed by municipalities, simply because it is not economically feasible due to high energy costs and area limitation for containment process given the large amount of the daily sludge produced in major cities. Dewatering is widely used in large cities, and incineration and land fill by municipalities are also common. Currently, there is an ongoing legislative revision study in Turkey. EU regulates the issue by Council Directive 86/278/EEC since 1986, much earlier than Turkey. Significant health problems due fertilizer use of sewage sludge are not observed in Europe with regards to pathogens and organic compounds according to some experimental results by [42], [43] and [44] cited in [45]. However, [46] underline that there is a need to update the Council Directive 86/278/EEC using ecotoxicological tests to assess the risks because EU regulates only heavy metals of $\mathrm{Cd}, \mathrm{Cu}, \mathrm{Hg}, \mathrm{Ni}$, $\mathrm{Pb}$ and $\mathrm{Zn}$. Many, but not all EU member states and also UK developed their own criteria some of which are stricter than the Directive, and also including regulation of pathogens. Heavy metal contamination in land use, even after further treatment used is practically inevitable as reviewed in previous parts of the introduction, unless a great daily cost is sacrificed by municipalities. Ref. [47] makes a comprehensive review on sewage sludge utilization in Europe, indicates the associated risks and highlights the fact that although land filling is banned in many EU countries, still $18 \%$ of all European sewage sludge is used for land filling, $50 \%$ of it is spread on agriculture soils and $28 \%$ of it is incinerated according to EUROSTAT data. Ref. [48] cited in [47] reports that farmers and landowners' associations have been expressing their growing hostility toward the agricultural use of biosolids in Europe. No information has been found in the literature about a similar case for Turkish farmers and landowners' associations, indicating a lack of awareness on the risks of utilization of sewage sludge in Turkish agricultural producers.

\section{ESSENTIAL COMPONENTS OF THE CIRCULAR ECONOMIC ECO-BOG SYSTEM}

\section{A. Desulphurization of Fuel Gas Coming from Biogas Combustion and Sewage Sludge Incineration}

Utilization of desulphurized fuel gas is an essential component of the circular economic eco-bog system and it serves to the following purposes:

1) Fixation of sulphur on land;

2) Avoiding acid rain formation (i.e., $\mathrm{H}_{2} \mathrm{SO}_{4}$ production in the atmosphere);

3) Production of calcium sulphite fertilizer

$\mathrm{CaCO}_{3}($ solid $)+\mathrm{SO}_{2}($ gas $) \rightarrow \mathrm{CaSO}_{3}($ solid $)+\mathrm{CO}_{2}$ (gas)

4) Production of magnesium sulphite fertilizer

$\mathrm{Mg}(\mathrm{OH})_{2}($ solid $)+\mathrm{SO}_{2}($ gas $) \rightarrow \mathrm{MgSO}_{3}($ solid $)+\mathrm{H}_{2} \mathrm{O}($ liquid $)$

5) Production of sodium sulphite fertilizer

$$
2 \mathrm{NaOH}(\mathrm{aq})+\mathrm{SO}_{2} \text { (gas) } \rightarrow \mathrm{Na}_{2} \mathrm{SO}_{3}(\mathrm{aq})+\mathrm{H}_{2} \mathrm{O}(\text { liquid })
$$

The $\mathrm{CO}_{2}$ from article 3 above, can also be sent to gas storage tank through fuel to be used in both algaculture and eco-bog. Optionally, some utilization of rust $\left(\mathrm{Fe}_{2} \mathrm{O}_{3}\right.$ solution in water) for desulphurization will also produce $\mathrm{Fe}$ ions and $\mathrm{SO}_{4}$ ions after contact with $\mathrm{SO}_{2}$ fuel gas, which could also be used to produce $\mathrm{FeSO}_{4} .7 \mathrm{H}_{2} \mathrm{O}$. This $\mathrm{FeSO}_{4} .7 \mathrm{H}_{2} \mathrm{O}$ is an additive for advanced biological treatment systems. 


\section{B. Concrete Production from Cement and Cementitious Material Produced from Sewage Sludge ash and Eco-Bog Sedimentations}

Cement and concrete production from sewage sludge includes incineration of the sludge with an end product of ash to be processed into cement, and of fuel gases. Among the thermal methods of sewage sludge treatment, incineration method is the cheapest when compared with pyrolysis, gasification, and HTC methods [49]. Although the concrete production is recycling with a value addition, valuable fertilizer potential of the sewage sludge is lost in this case. Separation of nitrogen and phosphorus from sewage and sewage sludge by algae before incineration is possible by numerous techniques with varying degrees of efficiency reviewed very recently by [50]. The sewage sludge is allowed to be treated with algae in the eco-bog system at any stage before being processed into ash formation. Ref. [51], stating sewage sludge ash and cement have common properties in terms of major elements and hydraulic properties, measured that the cement from sewage sludge ash can be processed into mortar or concrete monolith, safe with regards to the contaminant content, whereas if the ash remains in the powder form, they contain Molybdenum and Selenium in unsafe amounts. Ref. [51] also concludes it is feasible to use sewage sludge ash to produce construction materials and in particular monolith concrete, albeit with strict chemical and mechanical prescriptions. Ref. [52], indicating that liquid sewage sludge ash can be successfully stabilized to produce composite materials, measured a range from 0.5 to $2.5 \mathrm{MPa}$ compressive strength for such composite materials. Ref. [53] showed that good quality light weight aggregate and light weight concrete can be obtained by mixing sewage sludge with waste glass in the form of glass powder. The only way to stop the life cycle of pathogenic organisms and the bacteria with antibiotic resistance genes which live in sewage sludge ecosystems, which are highly life supportive, is killing them. $\mathrm{UV}$, pasteurization, and thermal hydrolysis can remove living beings from sewage sludge; however chemical pollution e.g., caused by heavy metals remain. Furthermore, after removal of life from sewage sludge, the remaining life supportive medium of it would attract new life very fast, if not properly isolated. For a governmental notion, treatment of sewage sludge for totally healthy fertilizer means too much additional costs, and to remove all microbial life and heavy metals is expensive. Contaminants of emerging concerns are also a growing threat to be faced in land use of biosolids. For both developing and developed countries cement and concrete production from sewage sludge ash is a cheap option. With a notion of Earth system sciences, the waste that comes from lithosphere and biosphere to sewage part of hydrosphere eventually remains on lithosphere when it is processed into concrete to be used on lithosphere, rather than being used as fertilizer on lithosphere which has a direct path to groundwater part of hydrosphere, as well as a direct path to the biosphere by plant uptake, and human and animal contact to soil in agricultural areas, gardens, parks and nature.

\section{Algae Production with Vertical Agriculture}

Treated wastewater can have many uses including aquaculture and algaculture. Ref. [54] identified the three most important criteria for utilization of treated water as salinity, heavy metals and harmful organic substances, and pathogenic germs, and estimated the approximate range of Nitrogen to be $10-30 \mathrm{mg} / \mathrm{l}$ and Phosphorus to be $0.1-30 \mathrm{mg} / \mathrm{l}$ in treated wastewater, which are enough amounts when discharged to cause eutrophication, an ecologically undesired result but a consciously desired result in eco-bog system. Flue gas can be used to grow algae according to [55] and also according to [56]-[58] as exclusively cited in [59]. Average of $\mathrm{CO}_{2}$ fixation in different algae species is 1.8 tons of $\mathrm{CO}_{2}$ per 1 ton algae biomass according to [60] cited in [59]. [60] also concluded the utilization of photobioreactors to be producing much greater algae oil yield per hectare than the utilization of raceway pond for algaculture since volumetric biomass productivity of photobioreactors was more than 13 fold greater in his study for biodiesel production from algae. This algae life supporting property of treated wastewater which is a treat to discharged wetlands and marine ecosystems for algal blooms can be used as an opportunity to produce algae in a controlled environment. The circular economic eco-bog system uses vertical agriculture to produce algae by treated water and flue gases other than $\mathrm{SO}_{2}$. When the algae are separated, the remaining treated water with less phosphorus and some organic material is either taken back to the initial unit of the WWTP to circulate one more before final discharge or discharged. Before this latter type of discharge, UV disinfection and filtration of cytokines may be necessary also depending on the algae species used. The integrated assessment of EU on biomass production links the sustainable production of algae to realization of many EU policies, strategies, and directives, identifying algae production methods to be vital for carbon capture, sustainability, and circular economy [61]. The circular economic eco-bog system is not only making algaculture, but also produces an added value of utilization of fuel gases to produce soil carbon, by ecomimicry of lake evolution.

\section{DESIGN OF THE SYSTEM}

The aim of the design of the circular economic eco-bog system (Fig. 1) is not transferring the mass to the atmosphere; instead, it uses them in creation of additional biomass and soil carbon in the form of lake sedimentation in controlled amounts. These gases are used to produce algae by algaculture and also separately lichens in artificial bogs, which additionally make carbon and nitrogen capture. Sedimentation is further carbon and nitrogen sequestration by formation of organic soil and peat materials, as well as bigger aggregates. Indeed, this is an exceptionally climate friendly engineering design, totally inspired from the lake death mechanisms of the nature, rather than lake health mechanisms of the nature. For the initial design of healthy lake, treated water and the algae produced by vertical agriculture (Fig. 2) are placed in an artificial wetland ecosystem (Fig. 3) in the form of constructed and connected ponds (Fig. 4), with valve regulated type pipes for controlled water entrance and discharge, and with other valve regulated type pipes for controlled entrance of desulphurized flue gases. Following lichen formation either by natural microbial contamination or by addition of selected lichen fungi, gas valves are opened. Since the flue gas is desulphurised, no formation of $\mathrm{H}_{2} \mathrm{~S}$ is expected, which causes the bog smell in natural bog 
ecosystems, and which is harmful to humans. Lichen formation by either natural microbial contamination or physical addition of fungi or lichens initiates eutrophication which mimicries the natural lake evolution from healthy to unhealthy. $\mathrm{CO}_{2}$ and nitrogenous fuel gases continuously entering into the artificial pond, increasing hypoxic conditions, large availability of treated water with controlled release and discharge from the pond, and algae produced by vertical agriculture all together would mean a catastrophe for natural ecosystems, however here it is consciously designed so. Ref. [62] states algae grow extraordinarily well in most hydroponic culture systems. Sedimentation in the artificial lake includes dead lichens, microbiological soil and other secondary aggregation including weathering of lichens. This weathering is accelerated by addition of sand and stones used in hydroponic agriculture such as gravel, vermiculite, rockwool, perlite, peat moss, coir, or sawdust. Eco-bog is not a constructed wetland for treatment, and it never has an aim of water quality, but oppositely it is dealing with the mass removed from water to be used in concrete production, while at the same time making industrial production of lichens and bog ecosystem services for value addition to the overall industrial process and having added value of fixing the carbon and nitrogen gases. Eco-bog is designed to keep what belongs to lithosphere and biosphere to stay at their place by (a) fixing fuel gas masses of terrestrial carbon and nitrogen origin (b) fixing atmospheric carbon and nitrogen in biosphere and following the sedimentation transferring it into lithosphere.

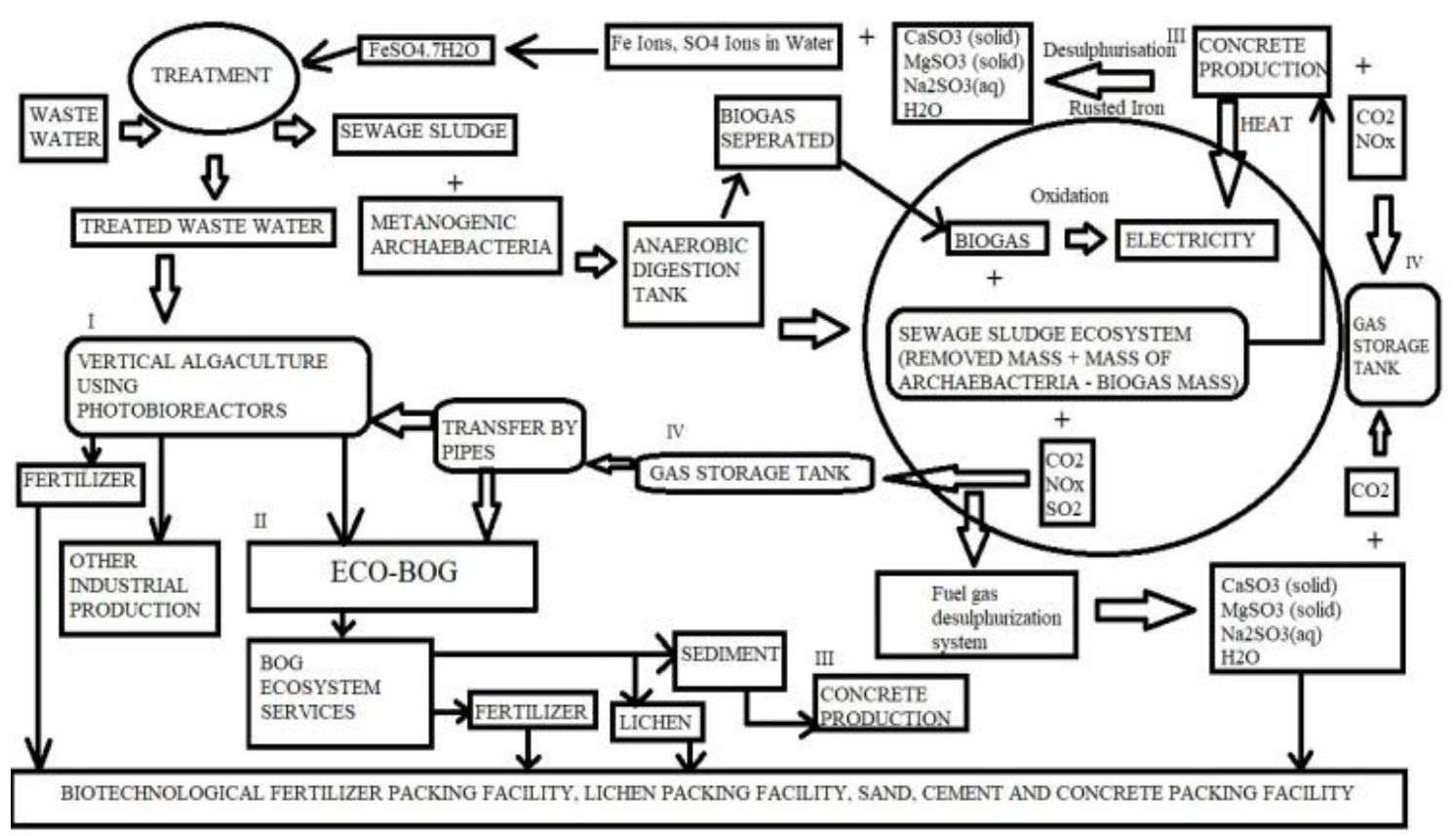

Fig. 1. General industrial process of circular economic eco-bog system (Refer to Fig. 2 for Roman number I, to Fig. 3 and 4 for Roman number II, to Fig. 5 for Roman number III). The roman number IV put on two points on the shape means that the same gas storage tank is used for storing desulphurized fuel gases.

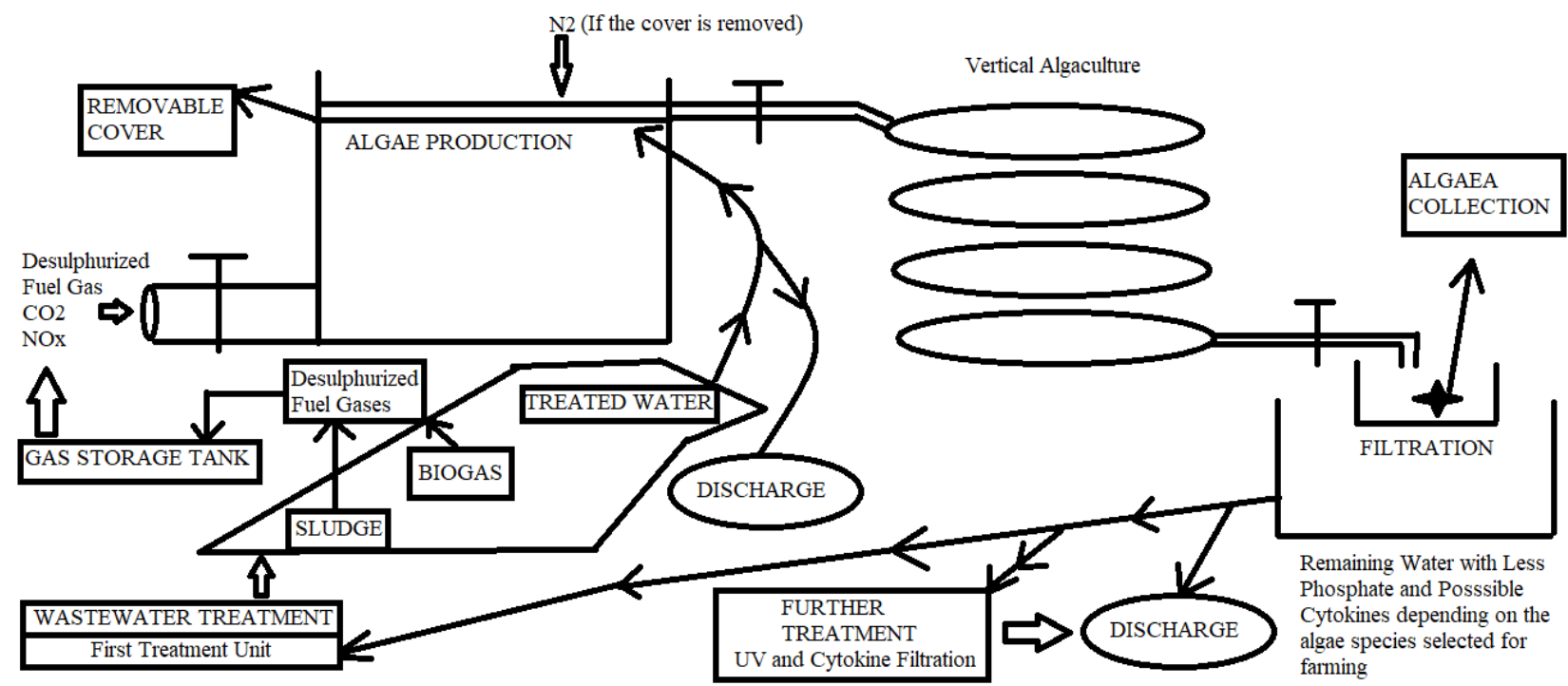

Fig. 2. Vertical algaculture using desulphurized fuel gases. Cytokines are toxic to humans, so uppermost work security measures should be taken. 


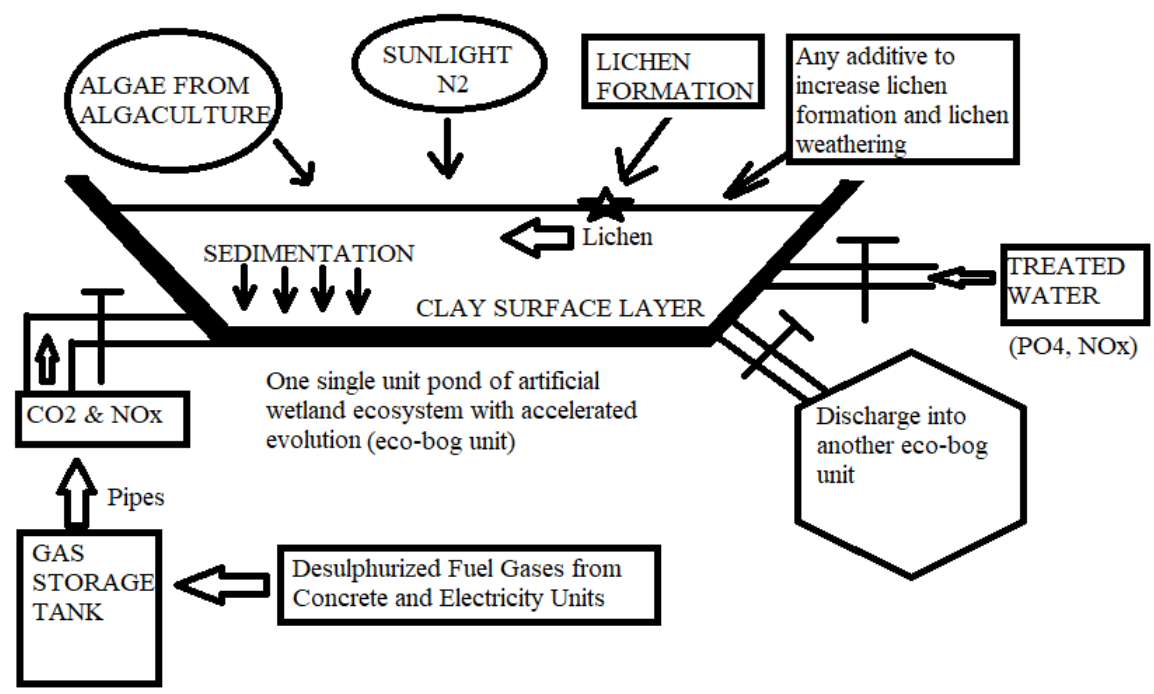

Fig. 3. Eco-bog unit is one single pond of artificial wetland ecosystem with accelerated evolution. Stones used in hydroponics should have a density lower than treated water to ensure that they suspend close to the surface for lichen weathering. Higher the quality of sand originating from microbial life in sedimentation, higher the cement quality will be achieved.

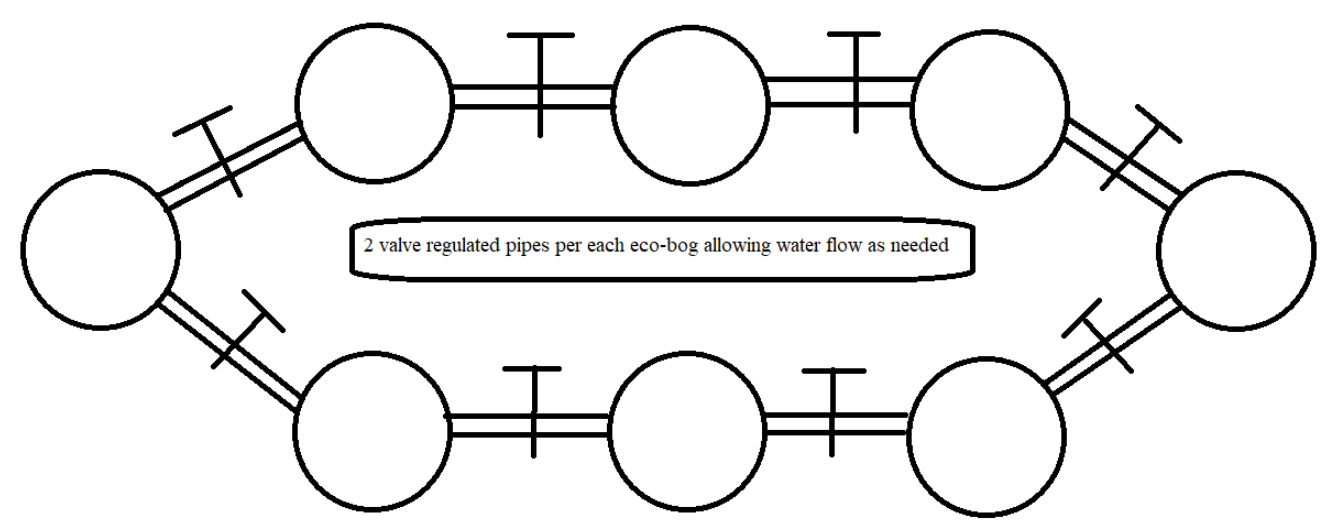

Fig. 4. Eco-bog ecosystem, as an artificial wetland ecosystem with accelerated evolution. Circular connection allows all possible water effluent and influent control during artificial lake evolution.

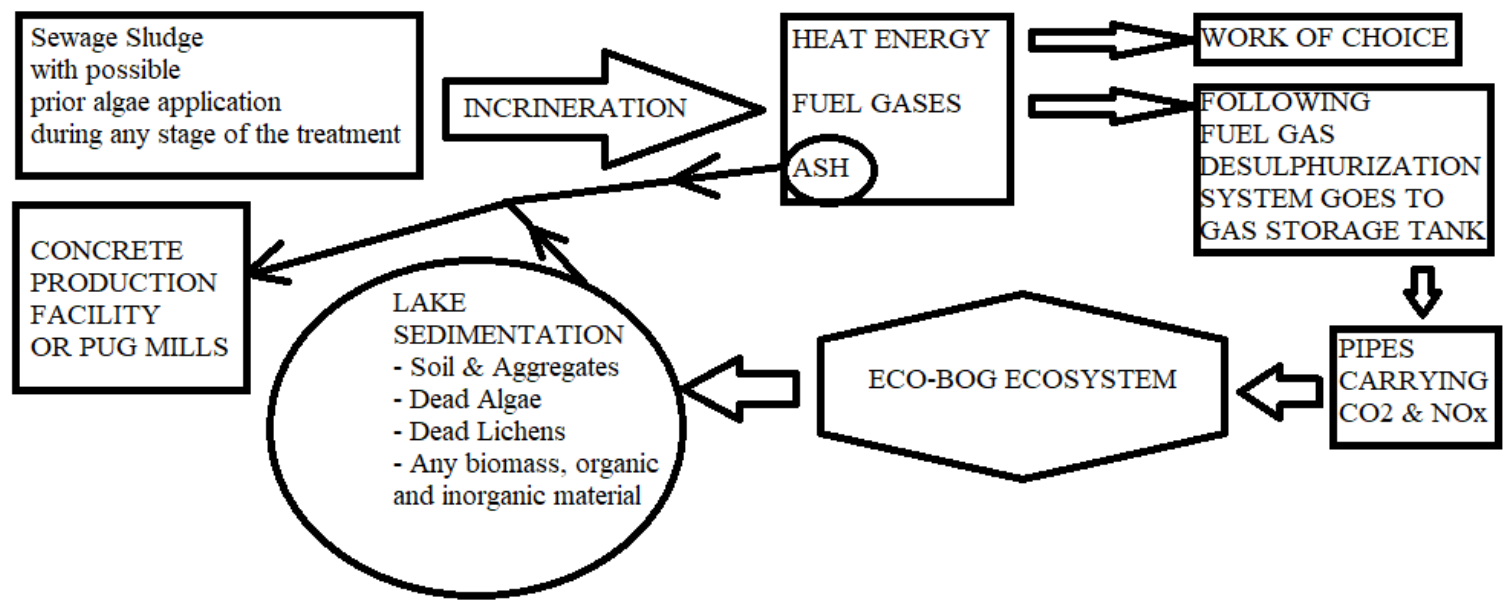

Fig. 5 Concrete production from cement using wastewater sludge ash and lake sedimentation material from eco-bog ecosystem (integrated ponds of eco-bog units). Different amounts of sand can be used depending on the sedimentation production capacity of each municipality.

Vertical agriculture and eco-bogs can use cyanobacteria, or any algae including microalgae. Chlorella sorokiniana and Asterarcys quadricellulare grow well under high temperature, $\mathrm{CO}_{2}$ and $\mathrm{NO}$ levels as measured by [59], also finding out that the former species produce more biomass. Although algae fix $\mathrm{N}_{2}$ from atmosphere producing ammonium ions in the cytoplasm, according to [55], still some nitrates of fuel gas could be available as an $\mathrm{N}$-source for the microalgae. In other words, the philosophy of the design is to combat climate change and to serve stopping the movement of mass between layers of earth occurring in WWTPs rather than to increase water quality. As a result, eco-bog produces the aggregate, soil, and biomass as bog ecosystem services (a) to be mixed with sludge ash for production of concrete with higher quality, (b) to be packed for utilization in different industries. 
Before processing sludge into cement as shown in (Fig. 5), production of hydrogen by appropriately designed techniques using hyperthermophilic bacteria and archaeabacteria, and with a pre-treatment to degrade existing microbial life [63] may be tested for feasibility. Caldicellulosiruptor bescii, formerly known as Anaerocellum thermophilum in microbiology literature before reclassification in 2010 [64] is a hyperthermophilic bacteria famous to have a natural life in geysers of Kamchatka, where it is first isolated from nature [65]. It is calculated by [66] that this species can yield maximum $86 \mathrm{~mL} \mathrm{H}_{2}$ per 1 gram (dryweight) biosolids. Heat produced to have sewage ash can be used to produce additional electricity [67] for the facility of WWTPs or used for any work of choice. Together with concrete and electricity production, final products of the system are compared with WWTPs without eco-bog system integration (Table II).

TABLE II: COMPARISON OF THE END-PRODUCTS OF ADVANCED TECHNOLOGY WWTPS WITHOUT AND WITH CIRCULAR ECONOMIC ECOBOG SYSTEM

\begin{tabular}{|c|c|c|}
\hline End-Products & $\begin{array}{c}\text { Advanced } \\
\text { Technology } \\
\text { WWTPs, when the } \\
\text { sludge is used as } \\
\text { fertilizer but not as } \\
\text { concrete }\end{array}$ & $\begin{array}{c}\text { Advanced Technology } \\
\text { WWTPs integrated with } \\
\text { Eco-bog System when the } \\
\text { sludge is used as concrete } \\
\text { only }\end{array}$ \\
\hline $\begin{array}{c}\text { Treated } \\
\text { Wastewater }\end{array}$ & Yes & $\begin{array}{l}\text { Yes (with less phosphorus } \\
\text { in minor amounts) }\end{array}$ \\
\hline Biogas & Yes & Yes \\
\hline Electricity & Yes (from Biogas) & $\begin{array}{c}\text { Yes (from Biogas \& } \\
\text { Sludge) }\end{array}$ \\
\hline Fertilizer & $\begin{array}{l}\text { Sewage sludge } \\
\text { fertilizer }\end{array}$ & $\begin{array}{l}\text { Microbial biofertilizer, } \\
\text { organic and organomineral } \\
\text { fertilizer, sulphurous } \\
\text { fertilizer }\end{array}$ \\
\hline $\begin{array}{c}\text { Soil and } \\
\text { Aggregates }\end{array}$ & No & Yes \\
\hline Concrete & No & Yes \\
\hline Industrial Algae & No & Yes \\
\hline Industrial Lichen & No & Yes \\
\hline
\end{tabular}

\section{THEORIZATION AND DISCUSSION ON THE WAY FORWARD}

The definitions of wastewater treatment based on a philosophy of engineering oriented to purify water, which are based on linear arguments on a value of having maximum quality treated water as the only aimed end product is the essential basis of constructing the WWTPs of today. Thus design of WWTPs are (a) not in harmony with nature including non-water nature, (b) neglecting the role of the physical law of conservation of mass in evolutionary ecosystem ecology and the biogeochemical cycles with interactions with hydrosphere, (c) neglecting the fact that sewage sludge is - an artificial ecosystem and a cocktail of heavy metals and contaminants of emerging concern - end products of an anthropogenesis ready to enter multiple ecological cycles in open biosphere if used as fertilizer or landfill no matter and whichever treatment is done on it.

The idealized general definition of water treatment, including wastewater treatment theorized in this study; based on distribution and flow of mass within Earth system, mathematical relations and covering the current and future digital industrial developments is the following argument: Water treatment is a non-linear anthropogenic system component of the Earth system, which is also internally an anthrobiogeochemically semi-cyclic system itself, functioning to separate unwanted mass and energy from hydrosphere by physical, chemical and biological interferences of humans and machines, ideally to have the maximum circular use and recycling of the separated mass and energy such that; retransfer of the separated mass back to hydrosphere is stopped and unnatural biological life cycles are terminated, while producing the highest quality of water possible and goods with economical value based on recycling of the removed mass and energy as final outputs of multiple processes embedded within the system.

This ideal definition postulate brings us to the following principles of water treatment, not from the perspective of water but from the perspective of what to do with the mass removed from water.

1) Maximum removal of the unwanted mass and energy from hydrosphere at the uppermost timescale possible.

2) Maximum recycling of this removed mass and energy on lithosphere and biosphere, without directly transferring to hydrosphere and atmosphere and without harming the natural life, plant health and animal health.

3) Terminating unnatural life cycles arising from removed biomass during treatment processes.

4) Negative carbon emission, zero sulphur and nitrogen emission, and maximum carbon and nitrogen sequestration in biosphere (algae and eco-bog) and in lithosphere (sedimentation and soil formation in eco-bog system).

5) Production of industrial products that replace those industrial products of whose conventional production have negative externalities for Earth system

Once we define the WWTPs as a main Earth system problem with many sub-problems, the scientific and engineering community will develop various new insights and designs fitting into local and general needs. We believe circular economic eco-bog system is very mostly, though not completely, fitting into the ideal definition of water treatment theorized, and mostly addresses the problems listed in Table I. One important aspect of problem formulation (Table I) is about legal concerns. Some countries do not have direct legislations limiting the content of sewage sludge or biosolids (a more attractive name hiding the sewage origin of the sludge) for land use. Some have and allow its land use after further treatment. However, the literature clearly indicates the risks for environmental health and human health in particular for contaminants of emerging concern and heavy metals. Literature also shows that some heavy metals do not accumulate in the edible portion of certain plants in significant amounts. Biological approach covers not only medicinal questions and concerns for human organisms, but also questions and concerns both for biomagnifications in other species and for the health of ecosystems without any anthropocentric view on where the heavy metals are located within the plant organisms to be eaten by human organisms. The ecological concern is not only about edibility, but also about having heavy metals of industry origin being spread through ill defined engineering to open terrestrial ecosystems or agricultural ecosystems which have direct contact with soil, ground water and various organisms including humans (and in particular farmers), based on a decision of policy makers and law makers without real ecological understanding. Once the industrial heavy metals are in the open ecosystem, there are various pathways of nature to carry 
them to the individual organisms of species, as well as to carry them back into hydrosphere. Similarly, microbial life cycles generated by fertilizer or land fill use of sewage sludge are artificial human interventions to nature in open biosphere. As a result, the ideal definition provided and the relevant principles postulated reject fertilizer and land fill utilization of sewage sludge and prefer to maximally terminate all life on sewage sludge, and maximally to pull its energy to heat and electricity energy, by total combustion, and use the remaining mass for concrete production together with ecobog sediments, while also allowing any algae application prior to combustion step to rescue some beneficial organic and inorganic materials, if desired. Eco-bog also has a hope to decrease the pillage of nature by quarries. At wide scale utilization, the production of cement and concrete also serves less utilization of natural mine deposits, including inorganic carbon, a case fitting into the 5th principle above. Municipalities and farmers also need fertilizers. The circular economic eco-bog system fills this gap by producing fertilizers from the eco-bog component, from the vertical algaculture component and from the desulphurization of fuel gases. Furthermore, it makes negative emission or zero emission or minor emission depending on the capacity built in a given municipality. Feasibility studies in different municipalities in the world can give more insight to this engineering question, and the system can be locally adapted and more developed to better fit to the WWTP problem of a given municipality on a location on Earth with its specific environmental conditions. Algae, lichen, and bog ecosystem services produced have a variety of uses in many industries such as agriculture, chemistry, biochemistry, pharmacology, cosmetics, energy, food, cellulose industries etc. The algae are produced with treated water in eco-bog system, thus do not have harmful concentrations of contaminants. Still, it can be disinfected by UV before application to vertical algaculture, but not to eco-bog. Because algae production requires health of ecosystem, but eco-bog requires death of wetland ecosystem and birth of terrestrial ecosystem (i.e., accelerated sedimentation and sequestration). Healthy algae yielded by algaculture are sent to reproduce and finally to death from maximum sedimentation in eco-bogs. In terms of carbon, carbon emission is captured by biosphere and sent back to lithosphere as soil and concrete. The philosophy of this technology is continuously flourishing and ending algae life in controlled environment; thus, it is like accelerated carbon farming that naturally occurs in normal bog ecosystems at long time scales. Various new engineering techniques can be developed for eco-bog system and any of its components inspired from nature. Eco-bog has potential use for life creation from all types of fuel gases; because it is creating photosynthetic primary level of ecological energy pyramid, as long as there is water, light and political will for not releasing any gas to atmosphere from lithosphere and biosphere. WWTPs have the first two prerequisites. Fuel gases can kill very many ecosystems, but they feed eco-bogs, of whose ecosystem services later feed other ecosystems in agriculture and nature. Desulphurized fuel gases can be collected in large tanks in industrial regions and be given to large and controlled municipal eco-bogs from the bottom of the pond or ponds. The lichens and additive hypotonic stones would capture carbon and nitrogen and the remaining unfixed gas would be released to atmosphere through the pond. Increasing photosynthesis initially will increase biomass and then increasing hypoxia will start sedimentation of the biomass. Eco-bog uses hydroponic approach to increase sedimentation because algae like these conditions, however sedimentation can be accelerated by addition of many other additives, on which lichen can make weathering work. Eventually after sedimentation, the bog materials will be collected, and the system will be restarted again. Briefly, creation of a healthy lake and killing it by fuel gases and by the help of the algae and doing this repeatedly at the same area would be a pure ecomimicry of lake evolution in controlled environment and mean great amounts of carbon and nitrogen sequestration. Drying of bogs which were huge carbon reservoirs was due to a historically wrong decision of humans with another ill defined philosophy of engineering disregarding carbon cycle, Earth system, ecosystem ecology, and harmony with nature. The circular economic eco-bog system, which does not have $\mathrm{H}_{2} \mathrm{~S}$ and doesn't smell like natural bogs, and which accelerates evolution of lakes in controlled environment, and which is creating bogs and collecting bog material in repeated sequences, challenge this problem with its totally nature inspired engineering philosophy. It is a technology trying to copy what nature does at long time intervals to produce terrestrial carbon by death of lakes, in which atmospheric carbon is fixed both before the death and during the death of the lake ecosystem. To accelerate this evolution, the eco-bog additionally uses fuel gases unlike the atmospheric carbon dioxide that happens in natural bog ecosystems, agriculturally produced algae and accelerated lichen weathering by addition of hydroponic stones. Also, for aesthetic reasons plantation in the riparian part of the eco-bog or within the eco-bog is possible with any kind of plant because the bog is using already treated water, not waste water. However, the plants for wetlands which are constructed for water treatment due high resistance capacity to dirty lake conditions as listed by [68] can also be used (Schoenoplectus lacustris, Phragmites australis, Typha latifolia, Nymphaea alba, Potamogeton gramineus, Hydrocotyle vulgaris, Eichhornia crassipes, Lemna minor, Potamogeton crispus, Littorella uniflora). Furthermore, any biomass would increase the organic content of the sedimentation in eco-bogs. Wide application of circular economic eco-bog system would create many jobs, globally. Construction and machine sector (eco-bogs, fuel gas desulphurization systems, gas tank, pipes, concrete facilities, packaging facilities), chemistry sector (cement production), agriculture sector (vertical agriculture of algae, also including industrial software development sector for digital vertical agriculture) and packaging sector would cause employment in each of WWTPs where this system is integrated Automotive (production and maintenance of pug mills) will also be positively affected.

The long name of the circular economic eco-bog system is "Integrated Production System of Algae, Lichen, Soil, Bog Products, Concrete, Microbial Biofertilizer, Organic Fertilizer and Sulphur Fertilizer with a Model of Wastewater Treatment, Biogas Production, Electricity Production and Artificial Wetland Ecosystem with Accelerated Evolution". We believe this article should be freely accessed and be opened to discussion of the scientific and engineering 
community for further development to serve in healing the world, and to serve to the realization of SDGs and the goals of the Paris Agreement, the goals of the RIO Conventions, the circular economy and bioeconomy targets of EU Green Deal, and in particular the zero carbon policy goals.

The theoretical approach provided specific to water treatment based on a critics of existing philosophy of engineering to be not holistic, can be generalized to all engineering. One of the mottos and visions of the United Nations Convention on Biological Diversity (UNCBD), which is the umbrella of all biodiversity related regional and global law in the world, is "Living in Harmony with Nature." The online glossary [69] of the Intergovernmental Platform on Biodiversity and Ecosystem Services (IPBES) define this vision based on its conceptual framework [70] as " $a$ perspective on good quality of life based on the interdependence that exists among human beings, other living species and elements of nature. It implies that we should live peacefully alongside all other organisms even though we may need to exploit other organisms to some degree." Being inspired from this vision of UNCBD and the definition of IPBES, we postulate "Theory of Holistic Engineering in Harmony with Nature" with the following principles:

1) Principle of Conservation of Natural Mass Distribution between Earth Layers: Not causing any unnatural mass transfer between Earth layers at the uppermost timescale possible.

2) Principle of Circular Economy: Maximum recycling of mass and energy.

3) Principle of Avoiding Unnatural Contamination of Biosphere: Terminating unnatural life cycles and anthropogenic contaminants in biosphere arising from engineering processes, to ensure that the natural life, plant health and animal health are not harmed.

4) Principle of Mimicry of Nature: Developing a holistic technological approach using biomimicry, ecomimicry and jeomimicry for engineering designs, rather than pure analytical approaches neglecting holistic nature.

5) Principle of Alternative Eco-Production: Production of industrial products that replace those industrial products of whose conventional production have negative externalities on Earth.

6) Principle of Leading Astray of Harmful Substances: Directing of the mass and energy that normally harms and even kills natural ecosystems to artificial ecosystems.

\section{REFERENCES}

[1] Elser J, Bennett E. Phosphorus cycle: A broken biogeochemical cycle. Nature. 2011 Oct 5;478(7367):29-31. doi: 10.1038/478029a. PMID: 21979027.

[2] Lahiri, Susmita \& Ghosh, Debarati \& Sarkar, Disan. (2018). Biogeochemical Cycling Bacteria and Nutrient Dynamics in Waste Stabilization Pond System. 10.1007/978-981-10-7248-2_2.

[3] Slocombe Stephen P., Zúñiga-Burgos Tatiana, Chu Lili, Wood Nicola J., Camargo-Valero Miller Alonso, Baker Alison. (2020). Fixing the Broken Phosphorus Cycle: Wastewater Remediation by Microalgal Polyphosphates. 10.3389/fpls.2020.00982.

[4] Saunders, A., Albertsen, M., Vollertsen, J. et al. The activated sludge ecosystem contains a core community of abundant organisms. ISME J 10, 11-20 (2016). https://doi.org/10.1038/ismej.2015.117.

[5] Wieland Ulrich. (2003) Water use and waste water treatment in the EU and in Candidate Countries, ISSN 1562-3106, Catalogue number: KS-
NQ-03-013-EN-N,

Available

at: https://ec.europa.eu/eurostat/documents/3433488/5537328/KS-NQ03-013-EN.PDF/4dada14f-aceb-4a0b-8a6e$9531 \mathrm{~b} 4 \mathrm{e} 01 \mathrm{c} 78$ ?version $=1.0$.

[6] Encyclopedia Britannica, https://www.britannica.com/technology/wastewater-treatment, Access: 8th of May 2021.

[7] World Health Organization (2006). Guidelines for the safe use of wastewater, excreta, and greywater. World Health Organization. p. 31 ISBN 9241546859. OCLC 71253096.

[8] Andersson, K., Rosemarin, A., Lamizana, B., Kvarnström, E., McConville, J., Seidu, R., Dickin, S. and Trimmer, C. (2016). Sanitation, Wastewater Management and Sustainability: from Waste Disposal to Resource Recovery Archived 2017-06-01 at the Wayback Machine. Nairobi and Stockholm: United Nations Environment Programme and Stockholm Environment Institute. ISBN 978-92-8073488-1, p. 56.

[9] Ellen Z. Harrison, Summer Rayne Oakes, Investigation of Alleged Health Incidents Associated with Land Application of Sewage Sludges Summer, NEW SOLUTIONS, Vol. 12(4) 387-408, 2002.

[10] Jansen, F., Dorny, P., Gabriël, S. et al. The survival and dispersal of Taenia eggs in the environment: what are the implications for transmission? A systematic review. Parasites Vectors 14, 88 (2021) https://doi.org/10.1186/s13071-021-04589-6.

[11] Havelaar, A.H., Furuse, K. and Hogeboom, W.M. (1986), Bacteriophages and indicator bacteria in human and animal faeces. Journal of Applied Bacteriology, 60: 255-262. https://doi.org/10.1111/j.1365-2672.1986.tb01081.x.

[12] S. Lahrich, F. Laghrib, A. Farahi, M. Bakasse, S. Saqrane, M.A. El Mhammedi. Review on the contamination of wastewater by COVID19 virus: Impact and treatment. Science of The Total Environment, Volume 751, 2021, 142325, ISSN 0048-9697, https://doi.org/10.1016/j.scitotenv.2020.142325.

[13] Naddeo, Vincenzo; Liu, Haizhou (2020). "Editorial Perspectives: 2019 novel coronavirus (SARS-CoV-2): what is its fate in urban water cycle and how can the water research community respond?". Environmenta Science: Water Research \& Technology. 6 (5): 1213 1216. doi:10.1039/D0EW90015J.

[14] Andrew F. Brouwer, Joseph N. S. Eisenberg, Connor D. Pomeroy, Lester M. Shulman, Musa Hindiyeh, Yossi Manor, Itamar Grotto, James S. Koopman, and Marisa C. Eisenberg. (2018). Epidemiology of the silent polio outbreak in Rahat, Israel, based on modeling of environmental surveillance data. PNAS November 6, 2018, 115 (45) E10625-E10633; https://doi.org/10.1073/pnas.1808798115.

[15] World Health Organization Regional Office for the Eastern Mediterranean (2004). Integrated Guide to Sanitary Parasitology. World Health Organization. p. 1. ISBN 92-9021-386-8. Available at:

[16] Belhaj D, Elloumi N, Jerbi B, Zouari M, Abdallah FB, Ayadi H, Kallel M. Effects of sewage sludge fertilizer on heavy metal accumulation and consequent responses of sunflower (Helianthus annuus). Environ Sci Pollut Res Int. 2016 Oct;23(20):20168-20177. doi: 10.1007/s11356016-7193-0. Epub 2016 Jul 19. PMID: 27430654.

[17] Singh RP, Agrawal M. Effects of sewage sludge amendment on heavy metal accumulation and consequent responses of Beta vulgaris plants. Chemosphere. 2007 May;67(11):2229-40. doi: 10.1016/j.chemosphere.2006.12.019. Epub 2007 Feb 7. PMID: 17289111.

[18] Carlton-Smith, 1987. C.H. Carlton-Smith Effects of Metals in SludgeTreated Soils on Crops. WRc Environment TR251, WRc Medmenham, Marlow (1987).

[19] Smith SR. A critical review of the bioavailability and impacts of heavy metals in municipal solid waste composts compared to sewage sludge. Environ Int. 2009 Jan;35(1):142-56. doi 10.1016/j.envint.2008.06.009. Epub 2008 Aug 8. PMID: 18691760.

[20] Singh RP, Agrawal M. Potential benefits and risks of land application of sewage sludge. Waste Manag. 2008;28(2):347-58. doi: 10.1016/j.wasman.2006.12.010. Epub 2007 Feb 22. PMID: 17320368

[21] Sigua, Gilbert \& Adjei, Martin \& Rechcigl, J.E. (2005). Cumulative and Residual Effects of Repeated Sewage Sludge Applications: Forage Productivity and Soil Quality Implications in South Florida, USA (9 pp). Environmental science and pollution research international. 12. 80-8. 10.1065/espr2004.10.220.

[22] Aparicio Ruiz, Pablo \& Schiano-Phan, Rosa \& Salmerón, José. (2018) Climatic applicability of downdraught evaporative cooling in the United States of America. Building and Environment. 136. 10.1016/j.buildenv.2018.03.039.

[23] Sigua, G., Myer, R., Coleman, S., Mackowiak, C., Adjei, M., Chase, C., \& Albano, J. (2011). Regional Distribution of Soil Phosphorus Across Congregation-Grazing Zones of Forage-Based Pastures with 
Cow-Calf Operations in Florida. Journal of Environmental Protection, 02, 408-417.

[24] Alvarenga P, Mourinha C, Farto M, Santos T, Palma P, Sengo J, Morais MC, Cunha-Queda C. Sewage sludge, compost and other representative organic wastes as agricultural soil amendments: Benefit versus limiting factors. Waste Manag. 2015 Jun;40:44-52. doi: 10.1016/j.wasman.2015.01.027. Epub 2015 Feb 21. Erratum in: Waste Manag. 2015 Oct;44():227. PMID: 25708406.

[25] Xianke Lin, Sichang Li, Zebin Wei, Yangmei Chen, Liang Hei, QiTang Wu. Indirect application of sludge for recycling in agriculture to minimize heavy metal contamination of soil. Resources, Conservation and Recycling, Volume 166, 2021, 105358, ISSN 0921-3449, https://doi.org/10.1016/j.resconrec.2020.105358.

[26] Elisabet Marti, Victoria Osorio, Marta Llorca, Lidia Paredes, Meritxell Gros, Chapter Five - Environmental risks of sewage sludge reuse in agriculture, Editor(s): Paola Verlicchi, Advances in Chemical Pollution, Environmental Management and Protection, Elsevier Volume 6, 2020, Pages 137-180, ISSN 2468-9289, ISBN 9780323856843, https://doi.org/10.1016/bs.apmp.2020.07.003.

[27] Li, Chengcheng \& Cabassud, C. \& Guigui, Christelle. (2014) Evaluation of membrane bioreactor on removal of pharmaceutical micropollutants: a review. Desalination and water treatment. 55. $10.1080 / 19443994.2014 .926839$

[28] Kucukunsal, S. and Icgen, B. (2020), Removal of antibiotic resistance genes in various water resources recovery facilities. Water Environ Res, 92: 911-921. https://doi.org/10.1002/wer.1286.

[29] Shengnan Li, Chaofan Zhang, Fengxiang Li, Tao Hua, Qixing Zhou, Shih-Hsin Ho, Technologies towards antibiotic resistance genes (ARGs) removal from aquatic environment: A critical review, Journal of Hazardous Materials, Volume 411, 2021, 125148, ISSN 0304-3894, https://doi.org/10.1016/j.jhazmat.2021.125148.

[30] Rayane Kunert Langbehn, Camila Michels, Hugo Moreira Soares, Antibiotics in wastewater: From its occurrence to the biological removal by environmentally conscious technologies, Environmental Pollution, Volume 275, 2021, 116603, ISSN 0269-7491, https://doi.org/10.1016/j.envpol.2021.116603.

[31] Weiyi Liu, Jinlan Zhang, Hang Liu, Xiaonan Guo, Xiyue Zhang, Xiaolong Yao, Zhiguo Cao, Tingting Zhang. A review of the removal of microplastics in global wastewater treatment plants: Characteristics and mechanisms, Environment International. Volume 146. 2021 106277. ISSN https://doi.org/10.1016/j.envint.2020.106277.

[32] Satinder K. Brar, Mausam Verma, R.D. Tyagi, R.Y. Surampalli, Engineered nanoparticles in wastewater and wastewater sludge Evidence and impacts, Waste Management, Volume 30, Issue 3, 2010, Pages 504-520, ISSN https://doi.org/10.1016/j.wasman.2009.10.012.

[33] Chukwuemeka O. Nnaji, Jaison Jeevanandam, Yen S. Chan, Michael K. Danquah, Sharadwata Pan, Ahmed Barhoum. Chapter 6 Engineered nanomaterials for wastewater treatment: current and future trends. Editor(s): Ahmed Barhoum, Abdel Salam Hamdy Makhlouf. In Micro and Nano Technologies, Fundamentals of Nanoparticles, Elsevier, 2018. Pages 129-168. ISBN 9780323512558, https://doi.org/10.1016/B978-0-323-51255-8.00006-9.

[34] Timothy L. Coggan, Damien Moodie, Adam Kolobaric, Drew Szabo, Jeff Shimeta, Nicholas D. Crosbie, Elliot Lee, Milena Fernandes, Bradley O. Clarke. An investigation into per- and polyfluoroalky substances (PFAS) in nineteen Australian wastewater treatment plants (WWTPs). Heliyon, Volume 5, Issue 8. 2019. e02316. ISSN 24058440. https://doi.org/10.1016/j.heliyon.2019.e02316.

[35] Shigei, Makoto \& Ahren, Lutz \& Hazaymeh, Ayat \& Dalahmeh, Sahar. (2020). Per- and polyfluoroalkyl substances in water and soil in wastewater-irrigated farmland in Jordan. Science of The Total Environment. 716. 137057. 10.1016/j.scitotenv.2020.137057.

[36] Elizabeth F. Davis, Susan L. Klosterhaus, Heather M. Stapleton. Measurement of flame retardants and triclosan in municipal sewage sludge and biosolids. Environment International, Volume 40, 2012, Pages $1-7, \quad$ ISSN $0160-4120$, https://doi.org/10.1016/j.envint.2011.11.008.

[37] Kim, Un-Jung; Oh, Jung Keun; Kannan, Kurunthachalam (2017): Occurrence, Removal, and Environmental Emission of Organophosphate Flame Retardants/Plasticizers in a Wastewater Treatment Plant in New York State. ACS Publications. Collection. https://doi.org/10.1021/acs.est.7b02035.

[38] Ike van der Veen, Jacob de Boer. Phosphorus flame retardants: Properties, production, environmental occurrence, toxicity and analysis. Chemosphere, Volume 88, Issue 10, 2012, Pages 1119-1153, ISSN 0045-6535, https://doi.org/10.1016/j.chemosphere.2012.03.067.

[39] García-Agustín, Flors, Cerezo, et al. Aquifer Contamination by Nitrogen After Sewage Sludge Fertilization. Bull Environ Contam
Toxicol 72, 344-351 (2004). https://doi.org/10.1007/s00128-0038984-9.

[40] Hale Stephen S., Cicchetti Giancarlo, Deacutis Christopher F. 2016 Eutrophication and Hypoxia Diminish Ecosystem Functions of Benthic Communities in a New England Estuary.Frontiers in Marine Science, Volume 3, p 249, ISSN=2296-7745, doi 10.3389/fmars.2016.00249.

[41] Soledad González-Rubio, Ana Ballesteros-Gómez, Alexandros G Asimakopoulos, Veerle L.B. Jaspers. A review on contaminants of emerging concern in European raptors (2002-2020). Science of The Total Environment, Volume 760, 2021, 143337, ISSN 0048-9697, https://doi.org/10.1016/j.scitotenv.2020.143337.

[42] Gale et al. 2003, Pathogens in biosolids. Microbiological Risk Assessment. UKWIR, London, UK. ISBN: 1-84057-294-9

[43] Tanner et al 2008, Estimated Occupational Risk from Bioaerosols Generated during Land Application of Class B Biosolids, J Environ Qual.2008; 37: 2311-2321.

[44] Smith SC (2008), The implications for human health and the environment of recycling biosolids on agricultural land. Imperial College London Centre for Environmental Control and Waste Management. Available at: http:/www3.imperial.ac.uk/ewre.

[45] EU 2008, Environmental, economic and social impacts of the use of sewage sludge on land. Available at: https://ec.europa.eu/environment/archives/waste/sludge/pdf/part_i_re port.pdf.

[46] Hudcová H., Vymazal J., Rozkošný M. (2019): Present restrictions of sewage sludge application in agriculture within the European Union Soil \& Water Res., 14: 104-120.

[47] Collivignarelli, Maria \& Abbà, Alessandro \& Frattarola, Andrea \& Carnevale Miino, Marco \& Padovani, Sergio \& Katsoyiannis, Ioannis $\&$ Torretta, Vincenzo. (2019). Legislation for the Reuse of Biosolids on Agricultural Land in Europe: Overview. Sustainability. 11. 6015 $10.3390 /$ su 11216015 .

[48] European Commission. 2001. Disposal and Recycling Routes for Sewage Sludge Part 1-Sludge Use Acceptance, Report. Available online:

https://ec.europa.eu/environment/archives/waste/sludge/pdf/sludge_di sposal1.pdf (accessed on 10 May 2021).

[49] Đurđević, D.; Trstenjak, M.; Hulenić, I. Sewage Sludge Thermal Treatment Technology Selection by Utilizing the Analytical Hierarchy Process. Water 2020, 12, 1255. https://doi.org/10.3390/w12051255.

[50] Seyedeh Fatemeh Mohsenpour, Sebastian Hennige, Nicholas Willoughby, Adebayo Adeloye, Tony Gutierrez, Integrating microalgae into wastewater treatment: A review, Science of The Total Environment, Volume 752, 2021, 142168, ISSN 0048-9697, https://doi.org/10.1016/j.scitotenv.2020.142168.

[51] Maozhe Chen, Denise Blanc, Mathieu Gautier, Jacques Mehu, Rémy Gourdon, Environmental and technical assessments of the potential utilization of sewage sludge ashes (SSAs) as secondary raw materials in construction, Waste Management, Volume 33, Issue 5, 2013, Pages 1268-1275, ISSN https://doi.org/10.1016/j.wasman.2013.01.004.

[52] Primož Pavšič, Ana Mladenovič, Alenka Mauko, Sabina Kramar, Matej Dolenec, Ernest Vončina, Katarina Pavšič Vrtač, Peter Bukovec, Sewage sludge/biomass ash based products for sustainable construction, Journal of Cleaner Production, Volume 67, 2014, Pages 117-124, ISSN 0959-6526, https://doi.org/10.1016/j.jclepro.2013.12.034

[53] Bui Le Anh Tuan, Chao-Lung Hwang, Kae-Long Lin, Yuan-Yuan Chen, Mung-Pei Young, Development of lightweight aggregate from sewage sludge and waste glass powder for concrete, Construction and Building Materials, Volume 47, 2013, Pages 334-339, ISSN 09500618, https://doi.org/10.1016/j.conbuildmat.2013.05.039

[54] Kretschmer, N.; Ribbe, L. und Gaese, H. (2002). Wastewater Reuse for Agriculture. echnology Resource Management \& Development Scientific Contributions for Sustainable Development, Vol. 2.

[55] Varshney, Prachi \& Beardall, John \& Bhattacharya, Sankar \& Wangikar, Pramod. (2018). Isolation and biochemical characterisation of two thermophilic green algal species-Asterarcys quadricellulare and Chlorella sorokiniana, which are tolerant to high levels of carbon dioxide and nitric oxide. Algal Research. 30. 28-37.

[56] Brown, L M. Uptake of carbon dioxide from flue gas by microalgae. United Kingdom: N. p., 1996. Web. doi:10.1016/0196-8904(95)00347 9.

[57] Hauck JT, Olson GJ, Scierka SJ, Perry MB, Ataai MM (1996) Effects of simulated flue gas on growth of microalgae. Abstracts of Papers. American Chemical Society, 212.

[58] Doucha, Jiri \& Straka, František \& Lívanský, Karel. (2005). Utilization of flue gas for cultivation of microalgae (Chlorella sp.) in an outdoor open thin-layer photobioreactor. Journal of Applied Phycology. 17 403-412. 10.1007/s10811-005-8701-7. 
[59] Sjors van Iersel, "ALGAE-BASED BIOFUELS: A Review of Challenges and Opportunities for Developing Countries.", Review of FAO, May 2009, Retrieved 4 May 2021, from http://www.fao.org/fileadmin/templates/aquaticbiofuels/docs/0905_F AO_Review_Paper_on_Algae-based_Biofuels.pdf, Access: 04/05/2020.

[60] Chisti, Y. (2007). "Biodiesel from microalgae." Biotechnol. Adv. 25(3): 294-306.

[61] Camia A., Robert N., Jonsson R., Pilli R., García-Condado S., LópezLozano R., van der Velde M., Ronzon T., Gurría P., M'Barek R., Tamosiunas S., Fiore G., Araujo R., Hoepffner N., Marelli L., Giuntoli J., Biomass production, supply, uses and flows in the European Union. First results from an integrated assessment, EUR 28993 EN, Publications Office of the European Union, Luxembourg, 2018, ISBN978-92-79-77237-5, doi:10.2760/539520, JRC109869.

[62] Jr, J. (2014). Complete Guide for Growing Plants Hydroponically. $\mathrm{p} / 50.10 .1201 / \mathrm{b} 16482$.

[63] El-Qelish, M., Chatterjee, P., Dessì, P. et al. Bio-hydrogen Production from Sewage Sludge: Screening for Pretreatments and Semicontinuous Reactor Operation. Waste Biomass Valor 11, 4225-4234 (2020). https://doi.org/10.1007/s12649-019-00743-5.

[64] Yang SJ, Kataeva I, Wiegel J, Yin Y, Dam P, Xu Y, Westpheling J, Adams MWW. Classification of 'Anaerocellum thermophilum' strain DSM 6725 as Caldicellulosiruptor bescii sp. nov. Int J Syst Evol
Microbiol. 2010 Sep;60(Pt 9):2011-2015. doi: 10.1099/ijs.0.017731-0. Epub 2009 Oct 2. PMID: 19801388.

[65] Svetlichnyi, V. A.; Svetlichnaya, T. P.; Chernykh, N. A.; Zavarzin, G A. (1990). "Anaerocellum Thermophilum Gen. Nov Sp. Nov. an Extremely Thermophilic Cellulolytic Eubacterium Isolated from HotSprings in the Valley of Geysers". Mikrobiologiâ. 59: 598-604.

[66] Yasemin D. Yilmazel, David Johnston, Metin Duran, Hyperthermophilic hydrogen production from wastewater biosolids by Caldicellulosiruptor bescii, International Journal of Hydrogen Energy, Volume 40, Issue 36, 2015, Pages 12177-12186, ISSN 0360-3199, https://doi.org/10.1016/j.ijhydene.2015.06.140.

[67] Logan B. Generating electricity from wastewater treatment. Water Environ Res. 2005 May-Jun;77(3):211. PMID: 15969285.

[68] Vymazal J., Brix H., Cooper P. F., Green M. B., Haberl R. (1998). Constructed Wetlands for Wastewater Treatment in Europe. Backhuys Publishers. Leiden, Netherlands.).

[69] The IPBES Core Glossary, Available at: https://ipbes.net/glossary/living-harmony-nature, Accessed: 14.05.2021.

[70] Díaz S. et al, The IPBES Conceptual Framework — connecting nature and people, Current Opinion in Environmental Sustainability, Volume 14, 2015, Pages 1-16, ISSN 1877-3435, https://doi.org/10.1016/j.cosust.2014.11.002. 